\title{
Strengthening of Traditional Mud Houses on Response to Earthquake
}

\author{
Md Robiul Awall, Md Samdani Azad, Md Oli-Ur-Rahman, Sajib Sarker and Gazi Md Sharfaraz \\ Imam Azad
}

Received: 03 October 2019
Accepted: 11 November 2019
Published: 15 December 2019
Publisher: Deer Hill Publications
() 2019 The Author(s)
Creative Commons: CC BY 4.0

\begin{abstract}
Earthquake is an unexpected natural disaster that is unforeseeable and several earthquakes have been faced in Bangladesh with a magnitude of more than 6 in Richter scale in recent years. Non engineered houses are very common in rural area. Mudhouse is a typical house pattern among the non-engineered houses. The earthquake effect in conventional mud houses is a great concern. These houses are susceptible to earthquake damage due to some attributes of materials consisting of less stiffness, brittleness and poor bonding between the units. The present study deals with the strengthening of such houses using timber reinforcement with definite proportion contemplating the mud wall sizes and strengthening the walls by allowing some additional materials as reinforcements. Arrangements of reinforcement were followed in such a way that they would not require skilled labour and much cost. A finite element application STAAD-Pro was adopted to execute the required analysis of unreinforced and reinforced models considering both single story and double story. A series of analyses incorporating linear static and linear dynamic analyses were conducted to comprehend the actual response of models. Investigations from analyses depict that timber reinforcements impart greater stiffness and strength against overturning which increases the frequency of the structure and diminishes the lateral displacements to a good extent. The output from analyses includes lateral displacements, frequency, time-dependent displacements and time-dependent acceleration which depict the positive behaviour of reinforced mud houses. Such an arrangement of reinforcement can be a good choice to subside the detrimental effect of the earthquake.
\end{abstract}

Keywords: Mud house, Timber, STAAD. Pro, Earthquake, Reinforcement

\section{INTRODUCTION}

Construction of mud houses is a very common phenomenon among developing countries like Bangladesh. From the economic and social point of view, mud houses were considered a better choice in Bangladesh for centuries. Mud is one of the oldest and widely used building materials due to its advantage comprising of environmental friendliness, easy construction, and good thermal and acoustic properties. It is evident that about $30 \%$ of the world population still use mud houses as a residence and about $50-60 \%$ of houses are made of mud/adobe in the northern part of Bangladesh (Islam and Iwashita, 2010 [1]). There are variations in practices of making mud houses. Like using jute, straw, cow-dung, grass, iron sheets. Practicing of construction of mud houses has been continuing since the last few centuries. These houses are mainly of one, two or three-story houses. A two-story typical mud house is shown in Figure 1. Consideration of the story depends upon the family members and economic point of view. These houses are vulnerable to earthquakes and suffer serious structural damages or collapse. These problems include brittleness, weak joints, lack of structural integrity. Once yielding occurs, cracks development occurs in the adobe and results from a complete loss of tensile strength which may cause severe damage to the structure. On the contrary, unreinforced mortar is much weak and the connections between mud blocks become very sensitive against lateral loads induced from the earthquake. With a few shaking of earthquake vibration, this result partial or full disintegration of materials. Furthermore, for safety purposes, larger thickness mud walls are used to increase the seismic weight of the structure.

M. R. Awall1, M. S. Azad² $ه$, M. O. Rahman'1, S, Sarker³, G. M. S. I. Azad ${ }^{4}$

'Department of Civil Engineering, Rajshahi University of Engineering \& Technology, Bangladesh

${ }^{2}$ Department of Civil Engineering, University of Creative Technology Chittagong, Bangladesh

${ }^{3}$ Department of Civil Engineering, Kunsan National University, S. Korea

${ }^{4}$ Disha Engineering Ltd., Bangladesh

E-mail: samdani@uctc.edu.bd 


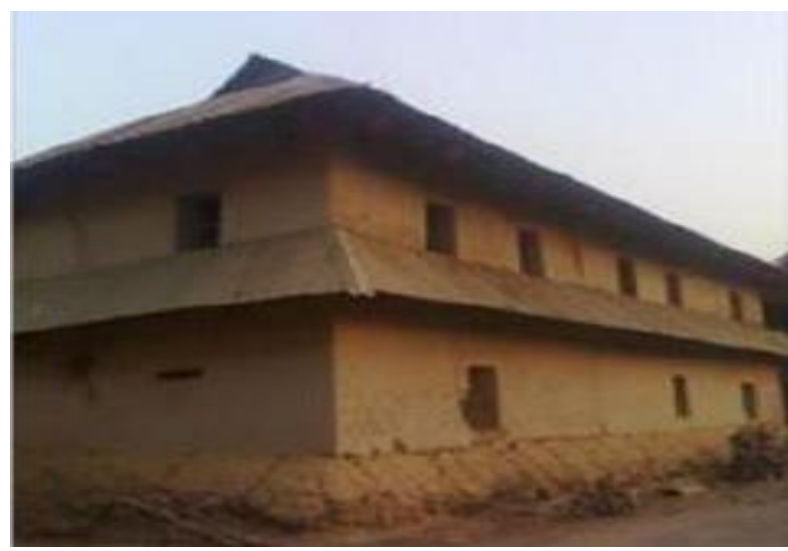

Figure 1: Two-story mud house in Manda, Naogaon

Previous researches define that using reinforcements, different materials can improve the performances of traditional mud houses. Islam and Iwashita [1] discussed the adobe or mud materials which were reinforced by low-cost materials. A series of lab experiments were carried out in the research. Straw, jute, cement were added to the mud block to improve the performance of such houses. In the case of straw, several facts were taken into consideration like as straw content, length of the straw, crushed straw and scale effect test of straw. In the case of jute, jute content, the length was the features of reflection. Furthermore, the effect of gypsum and clay content were considered. Finally, the effect of cement was also inspected. The outcome of the research deliberates that straw and jute increase the ductility while gypsum and cement improve the bonding. Meli et al. [2] represented the strengthening of adobe houses for seismic actions. An experimental shaking table test was regulated in this study. Only a part of the structure was considered in the test due to the table size requirements. Three strengthening method was adopted in the research consisting of using a concrete bond beam, using steel ties and using wire mesh and mortar. The output of the study delivered that strengthening methods cover the essential aspects of using reinforcements. Ottazzi et al. [3] delineated the shaking table tests to improved adobe masonry houses. A full-scale model was tested using a shaking table for assessing the performance of improved adobe masonry house. The reinforcement technique comprising of interior cane mesh and a crowning tie beam was adopted in the research. Research outcome illustrated that using such reinforcements improves the quality of structures against earthquakes. Further study on earthquake-resistant nonengineered building construction for a rural area in Bangladesh was narrated by Alam et al. [4] A vast study on damage analysis was carried out in this research. New techniques for strengthening mud, masonry and nonengineered Reinforced Cement Concrete (RCC) house were adopted in this paper. Conversely, economic consideration was also given priority. For mud house consideration, bamboo bracing in cross-orientation was considered. The denouement of the research gave a better idea for the present practice of non-engineered houses. Arya [5] studied on non-engineered construction in developing countries. Earthquake risks, its management, damages due to previous earthquakes, damage risks for non-engineered houses and some techniques for strengthening such houses were represented in this investigation. Various types of retrofitting schemes in earthen houses were studied. In addition to saving existing and future buildings, the schemes in this might be some good options. Uddin [6] reviewed on traditional housing technology in Bangladesh. This paper highlights the mud made house technology in Bangladesh. This paper explored the traditional housing technology, local's interpretation against disasters. Vargas et al. [7] explored the seismic strength of adobe masonry. They discussed the factors controlling the strength of adobe masonry, the effect of additives, improvements of adobe masonries by adding sands, straws. Several practical recommendations were delivered from this study. Bariola and Sozen [8] inspected seismic tests of adobe walls. Comprehensive research consisting of nine specimens and two types of ground motion was conducted. Performing shaking table tests, the base motion at failure were investigated. Besides, this failure types and response from shaking table tests were also noted. Rahman et al. [9] illustrated the seismic effects of the mud house. They analysed the crack pattern and made a comparison before using and after using reinforcement. Some studies on experimental and numerical analysis with improvement techniques are delineated in references [10-14]

The aim of this research includes a proposal for providing timber reinforcements in the mud wall following a particular manner. The proposed reinforcement arrangement is the simplest one which doesn't require skilled labour and techniques. Four different models have been taken into consideration. Model-1 is the unreinforced while Model2 is the reinforced single story model. Similarly, Model-3 is the unreinforced and Model-4 is the reinforced double story building. The main issue for considering two different stories is to get a comprehensive idea about the response of seismic forces. For maintaining practical provisions, seismic parameters of Naogaon district from the seismic zoning map of BNBC [15] have been taken into consideration. Analyses results are indicating that the arrangements of reinforcements in the mud houses can be a decent option if the material quality is properly maintained. 


\section{MODELING}

\subsection{Modelling of Mud House}

Modelling of mud house was conducted using a Finite Element Package STAAD-Pro V8i. The structure was discredited by 8-noded solid elements as shown in Figure 2. The solid elements used in STAAD-pro [16] have three translational and three rotational degrees of freedoms per node. Solid elements enable the solution of structural problems involving general three-dimensional stresses. For the present study, a typical mud house has been chosen with a door and three windows in case of a single-story and a door and seven windows for two-story mud houses. Two different levels have been incorporated to comprehend the actual response of mud houses against seismic loading. A squareshaped plan has been adopted for the research purpose which stipulates it as a single room. The Mud walls have been generated through mud blocks which are designated as solid elements. For modelling single-story mud houses, firstly a solid node has been generated. Then the node is translated along the $x$-direction. After performing this, the total line translated again along the z-direction. A floor plane can be observed after this operation. Then the mud wall has generated by maintaining clearance. In the case of modelling of double story, an additional story is added to the single story. The whole modelling process is illustrated in Figure 3.

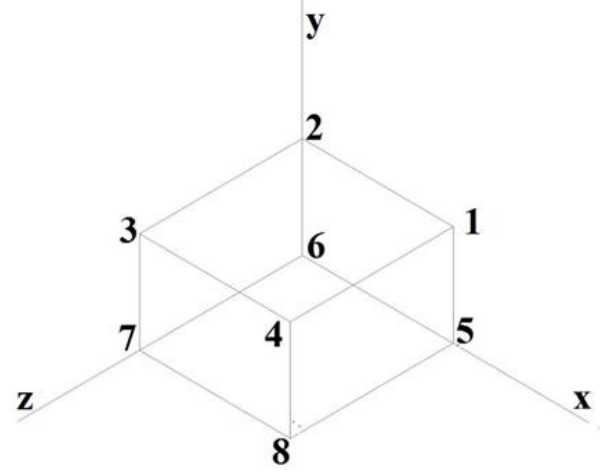

Figure 2: Eight node solid element in STAAD-pro V8i

8-noded Solid element

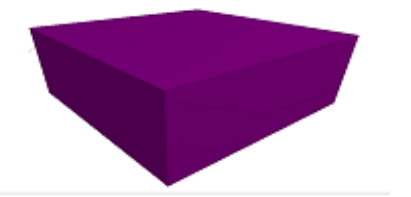

Translation along-y

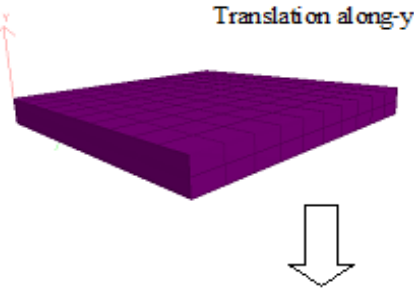

Form ation of single story

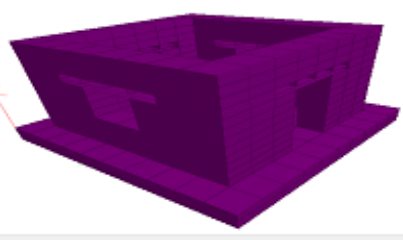

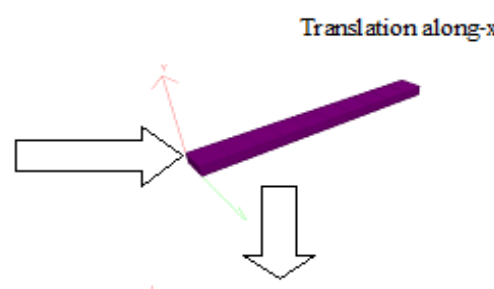

Trans ation along- $z$

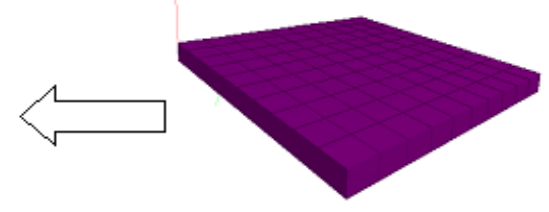

Formation of double story

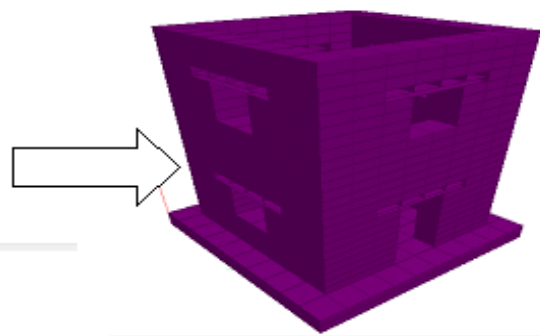

Figure 3: Step by step formation of mud house model 


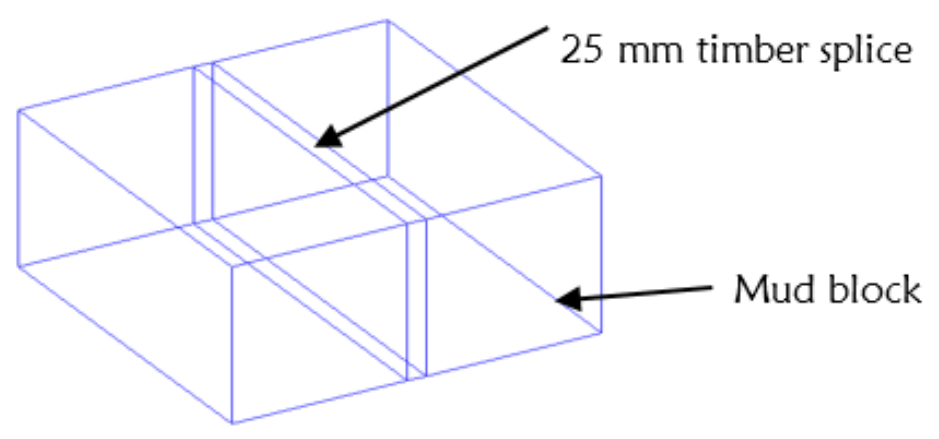

Figure 4: Arrangement of timber reinforcement in each mud block

Table 1: Relevant properties of used materials

\begin{tabular}{lcccc}
\hline \multirow{2}{*}{ Property } & \multicolumn{2}{c}{ US Customary unit } & \multicolumn{2}{c}{ SI unit } \\
\cline { 2 - 5 } & Mud & Timber & Mud & Timber \\
\hline Young's modulus (psi, kN/m²) & 12500 & 1332800 & 86184.4 & 9.18933 \\
Poisson' ratio & 0.45 & 0.15 & 0.45 & 0.15 \\
Density (pcf, $\left.\mathrm{kN} / \mathrm{m}^{3}\right)$ & 100 & 25 & 15.69 & 3.92 \\
Shear modulus $\left(\mathrm{psi}, \mathrm{kN} / \mathrm{m}^{2}\right)$ & 4310.35 & 579478 & 29718.8 & 316552 \\
\hline
\end{tabular}

\subsection{Modelling of Timber Reinforcement}

Timber splices were used as reinforcement through the mud wall to gain sufficient stiffness. This research aims to strengthen the mud house by providing timber reinforcement at the centre of the walls. The used timber splices are $25 \mathrm{~mm}$ in thickness. The section of the wall is provided as mud element and timber element as the 8-noded solid element is added further at the centre of the wall section. Thus, the timber reinforcement is provided although the walls excepting the openings. A single unit of the wall providing the mud element and timber reinforcement is shown in Figure 4. The relevant properties of materials have been considered from the research of Rahman et al. [9]. These properties have been represented in Table 1.

\section{SEISMIC ANALYSES}

Bangladesh National Building Code [15] has specifications for seismic analysis and zone coefficients that are adopted from the earthquake zoning map of Bangladesh. Other parameters, in which earthquake forces are dependent like structural importance factor, soil profile type, response modification factor are considered as per UBC1997 [17]. Both static and dynamic analyses of mud houses were incorporated into this study.

\subsection{Static Analysis}

In the case of static analysis, the seismic force is assumed to be acted as static forces. There are provisions in different codes for static analysis. As a rule, regular-shaped buildings with a height below $75 \mathrm{~m}$ are in the range in which engineers can adopt a static method of analysis. On the contrary, irregular buildings with a height below $20 \mathrm{~m}$ can be taken in such consideration as per UBC1997 [17]. Irregularity of structures based on different criteria and assumptions.

\subsection{Equivalent Static Force Analysis}

In this research, the equivalent static force method has been adopted for static analysis. If equivalent static force method is selected for seismic analysis of a building, the design seismic forces, their vertical distribution over the height of the building, and the corresponding internal forces will be calculated and determined as per UBC [17] code provisions to which are given in Equations (1-4). From the static analysis, some attributes have been noted. The outcome from this analysis comprehends lateral displacements and developed stresses in the mud wall.

$$
\begin{aligned}
& V=\frac{\mathrm{C}_{\mathrm{V}} \mathrm{I}}{\mathrm{RT}} \mathrm{W} \\
& V=\frac{2.5 \mathrm{C}_{\mathrm{a}} \mathrm{I}}{\mathrm{R}} \mathrm{W} \\
& V=0.11 C_{a} / W \\
& T=C_{t}\left(h_{n}\right)^{3 / 4}
\end{aligned}
$$

Where, $C t=0.020$ (0.0488) for all other buildings; $W=$ Total seismic weight of the building; $C v=0.32$ and $C a=$ $0.24 ; R=$ Response modification factor $=2.9$; Soil profile $=S c ; T=$ Structural period, which can be calculated from equation (4); I = Structural importance factor $=1$. 
Table 2 shows the differences in lateral displacements of different models. The unreinforced models face greater displacements considering the reinforced models. Considering a single-story mud house, the unreinforced one is with a displacement of $6.35 \mathrm{~mm}$ and $5.72 \mathrm{~mm}$ along $x$ and $z$ directions. On the contrary, the reinforced samples are susceptible to less deflection with $4.14 \mathrm{~mm}$ and $3.41 \mathrm{~mm}$ along with the corresponding directions. The percentages of lessening due to using reinforcement are $34.8 \%$ and $40.38 \%$. Contemplating the double story mud houses, substantial differences can also be observed. Unreinforced one is with displacements of $20.26 \mathrm{~mm}$ and $19.46 \mathrm{~mm}$ while the reinforced one is $7.09 \mathrm{~mm}$ and $6.9 \mathrm{~mm}$ along $x$ and $z$ directions. The percentages of reducing displacements are $65 \%$ and $64.54 \%$ which defies the use of unreinforced models.

\subsection{Dynamic Analysis}

In the case of dynamic analysis, the seismic force is assumed as dynamic loads. Response spectrum analysis and time history analysis are considered in this study.

\subsubsection{Response Spectrum Analysis}

Dynamic analysis using the response spectrum method is the method of calculating peak modal responses for sufficient modes to capture at least $90 \%$ of the participating modal mass of the building. A particular damping ratio is taken considering the property of structure materials. Normalized response spectra considering the soil profile and relevant co-efficient is to be made for the analysis purpose. Displacements, story forces, story shears, and base reactions for each mode of response can be combined following two methods consisting of square root sum of squares (SRSS) rule or the complete quadratic combination (CQC). This method of analysis is to be done by using normalized response spectra as dynamic loads [17]. These parameters can be deduced from the inputs consisting of the soil profile and seismic coefficient $(\mathrm{Ca}$ and $\mathrm{Cv}$ ). Soil type $=\mathrm{Sc}, \mathrm{Ca}=0.24, \mathrm{Cv}=0.32$, short period, $\mathrm{Ts}=\mathrm{Cv} / 2.5 \mathrm{Ca}=0.53 \mathrm{~s}$, fundamental period, $\mathrm{TO}=0.2 \mathrm{Ts}=0.1067 \mathrm{~s}$. The response spectra used in this research are represented in Figure 5 . It has been observed from Table 3 that the lateral displacements from response spectrum analysis exhibit a similar behaviour like the static analysis. But the numerical values are not alike at all. The dynamic analysis was incorporated by considering normalized response spectra.

Table 2: Displacements from equivalent static force analysis

\begin{tabular}{ccccccc}
\hline & $\begin{array}{c}\text { Single story } \\
\text { un-reinforced }\end{array}$ & $\begin{array}{c}\text { Single story } \\
\text { reinforced }\end{array}$ & \% decreasing & $\begin{array}{c}\text { Double story } \\
\text { un-reinforced }\end{array}$ & $\begin{array}{c}\text { Double story } \\
\text { reinforced }\end{array}$ & \% decreasing \\
\hline $\begin{array}{c}\text { Along } \\
\text { X (mm) }\end{array}$ & 6.35 & 4.14 & $34.80 \%$ & 20.26 & 7.09 & $65.00 \%$ \\
$\begin{array}{c}\text { Along } \\
\text { (mm) }\end{array}$ & 5.72 & 3.41 & $40.38 \%$ & 19.46 & 6.90 & $64.54 \%$ \\
\hline
\end{tabular}

Table 3: Displacements from response spectrum analysis

\begin{tabular}{ccccccc}
\hline & $\begin{array}{c}\text { Single story } \\
\text { unreinforced }\end{array}$ & $\begin{array}{c}\text { Single story } \\
\text { reinforced }\end{array}$ & \% decreasing & $\begin{array}{c}\text { Double story } \\
\text { unreinforced }\end{array}$ & $\begin{array}{c}\text { Double story } \\
\text { reinforced }\end{array}$ & \% decreasing \\
\hline $\begin{array}{c}\text { Along } \\
\text { X(mm) }\end{array}$ & 9.64 & 6.66 & $30.91 \%$ & 35.40 & 13.12 & $62.93 \%$ \\
$\begin{array}{c}\text { Along } \\
\text { Z(mm) }\end{array}$ & 9.18 & 5.59 & $39.10 \%$ & 33.88 & 13.01 & $61.59 \%$ \\
\hline
\end{tabular}

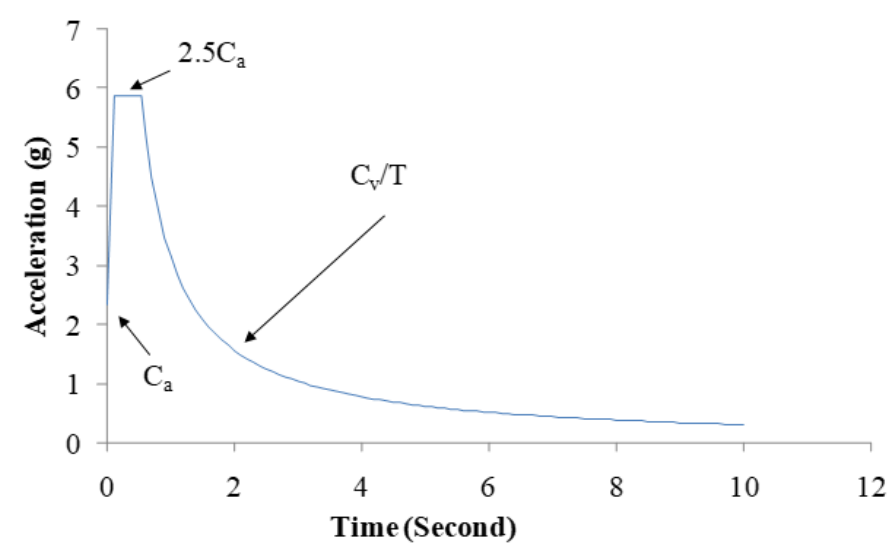

Figure 5: Response spectrum graph as per UBC1997 
The displacement values are almost double concerning the values of static analysis. But there is a reduction of displacements while using timber splices as reinforcements. The percentages of reducing displacements in single-story models are $30.91 \%$ and $39.10 \%$ to the corresponding directions. On the other hand, the reduction percentages for the double story are $62.93 \%$ and $61.59 \%$. The percentages of reduction of displacements are nearly the same in both static and response spectrum analysis.

Table 4 defines the differences in frequencies of different models due to dynamic loading. It is understandable from the result that the reinforced samples are with greater values of frequencies considering the unreinforced ones. The greater values of frequencies define greater stiffness of the above structures. It is observed from the mode shape analysis that, the first torsion mode is found in the third mode for the unreinforced case and the reinforced case, the first torsion mode is found in the fourth mode. This phenomenon can be observed for both single story and double story houses which are represented in Figures 6-7. The vulnerability of unreinforced models can be predicted from this mode shape observation. The modal analysis results are obtained from STAAD.Pro software package [16]. Figure 6 demonstrates the 1st torsion mode for the single story building (Unreinforced and reinforced). For unreinforced condition, the first torsion mode is found at third mode: $6.293 \mathrm{~Hz}$. Besides, the torsion mode shifts to fourth mode: $9.166 \mathrm{~Hz}$. This phenomenon illustrates the added stiffness through the timber reinforcements. Figure 7 depicts the first torsion modes of two story mud houses that include unreinforced and reinforced condition. For unreinforced condition, the first torsion mode is developed at third mode: $4.021 \mathrm{~Hz}$. In addition, this torsion mode shifts to fourth mode: $7.11 \mathrm{~Hz}$. It is evident that the reinforcement imparts additional stiffness which influences the modal response of the structures.

\subsubsection{Time History Analysis}

El Centro [18] earthquake acceleration data are shown in Figure 8 is considered as an input parameter of time history analysis. Table 5 conveys the maximum lateral displacements from linear time history analysis. It defines that the use of timber reinforcement reduces the lateral displacements to a good extent. A reduction of lateral displacement of more than $60 \%$ ensures the affectivity of using timber reinforcements.

Table 4: Frequency analysis

\begin{tabular}{ccccc}
\hline \multicolumn{5}{c}{ Frequencies $(\mathrm{Hz})$} \\
\hline Mode & $\begin{array}{c}\text { Single story } \\
\text { unreinforced }\end{array}$ & $\begin{array}{c}\text { Single story } \\
\text { reinforced }\end{array}$ & $\begin{array}{c}\text { Double story } \\
\text { unreinforced }\end{array}$ & $\begin{array}{c}\text { Double story } \\
\text { reinforced }\end{array}$ \\
\hline 1 & 5.195 & 6.678 & 2.516 & 4.443 \\
2 & 5.686 & 6.806 & 2.598 & 4.852 \\
3 & 6.293 & 7.709 & 4.021 & 6.665 \\
4 & 6.772 & 9.266 & 5.178 & 7.111 \\
5 & 7.831 & 11.013 & 6.588 & 7.674 \\
\hline
\end{tabular}

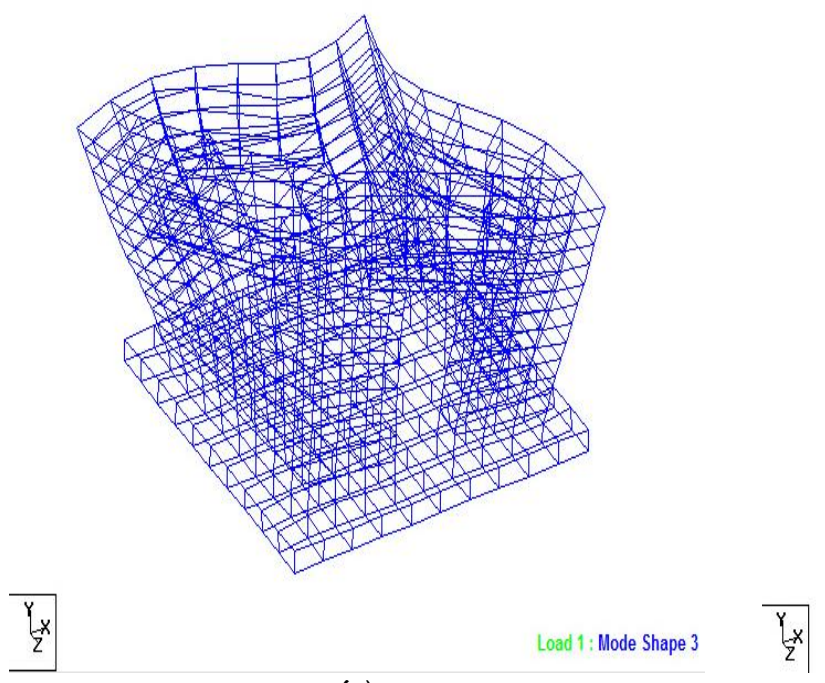

(a)

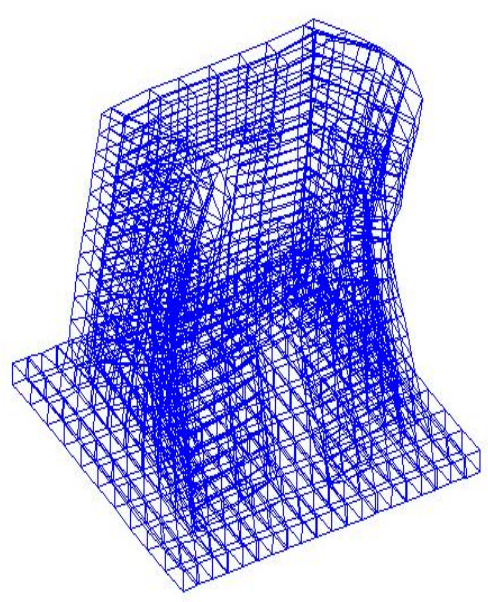

(b)

Figure 6. First torsion mode shape model of (a) unreinforced (Mode 3, $6.293 \mathrm{~Hz}$ ) single story and (b) reinforced single story (Mode 4, $9.166 \mathrm{~Hz}$ ) 


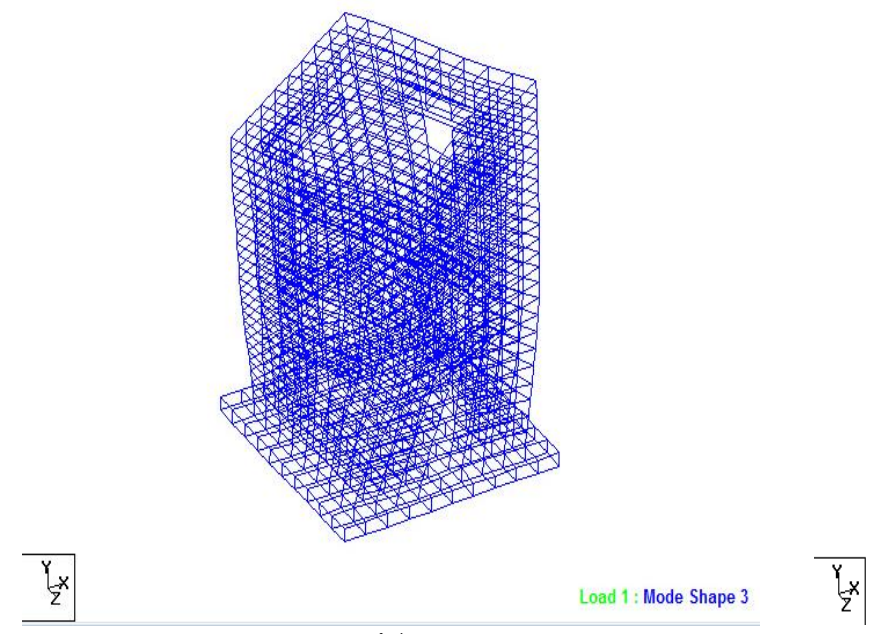

(a)

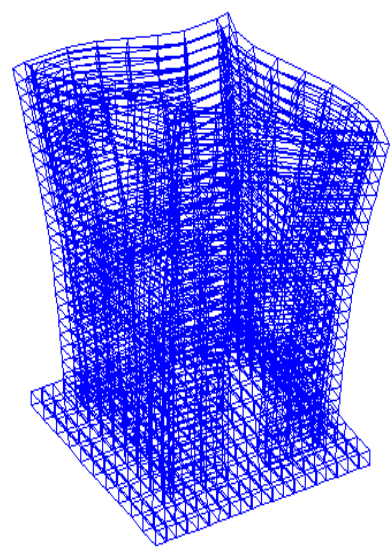

(b)

Figure 7. First torsion mode shape model of (a) unreinforced (Mode 3, $4.021 \mathrm{~Hz}$ ) double story and (b) reinforced double story (Mode 4, $7.11 \mathrm{~Hz}$ )

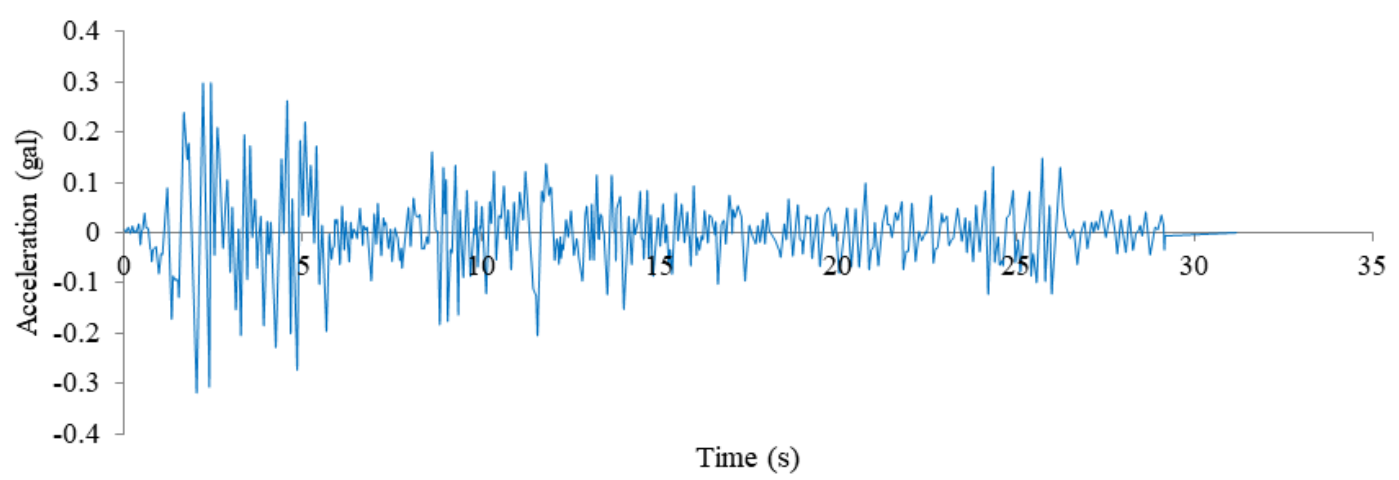

Figure 8: El Centro earthquake acceleration data

(a)

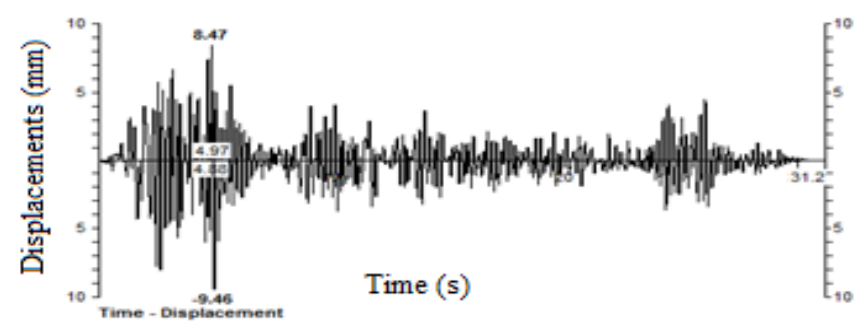

(b)

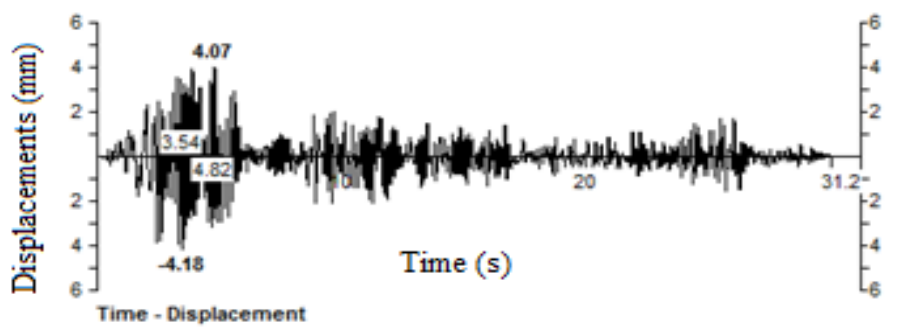

Figure 9: Time-dependent peak-to-peak displacements along $\mathrm{x}$-direction for single story (a) unreinforced (17.93 $\mathrm{mm}$ ) and $(\mathrm{b})$ reinforced $(8.25 \mathrm{~mm})$ structure. 
Table 5: Displacements from time history analysis

\begin{tabular}{ccccccc}
\hline & $\begin{array}{c}\text { Single story } \\
\text { unreinforced }\end{array}$ & $\begin{array}{c}\text { Single story } \\
\text { reinforced }\end{array}$ & $\begin{array}{c}\text { Percentage } \\
\text { decreasing }\end{array}$ & $\begin{array}{c}\text { Double story } \\
\text { unreinforced }\end{array}$ & $\begin{array}{c}\text { Double story } \\
\text { reinforced }\end{array}$ & $\begin{array}{c}\text { Percentage } \\
\text { decreasing }\end{array}$ \\
\hline $\begin{array}{c}\text { Along- X } \\
(\mathrm{mm})\end{array}$ & -15.04 & -7.84 & 47.83 & -45.21 & -13.8 & 69.48 \\
$\begin{array}{c}\text { Along Z } \\
(\mathrm{mm})\end{array}$ & -13.16 & -6.36 & 51.67 & -41.91 & -16.4 & 60.87 \\
\hline
\end{tabular}

(a)

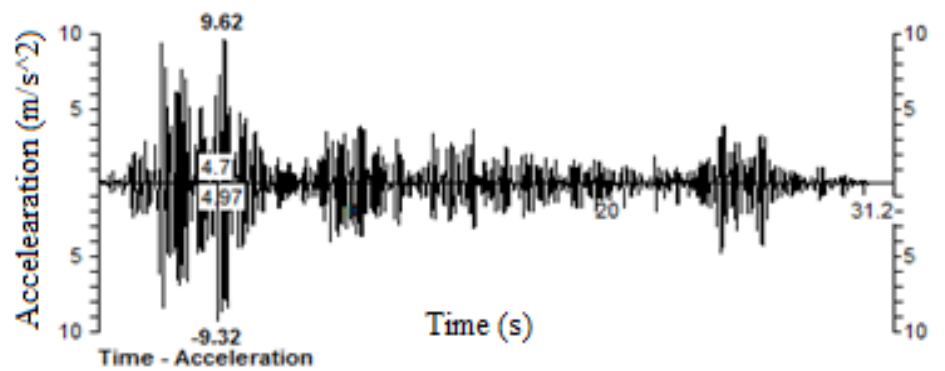

(b)

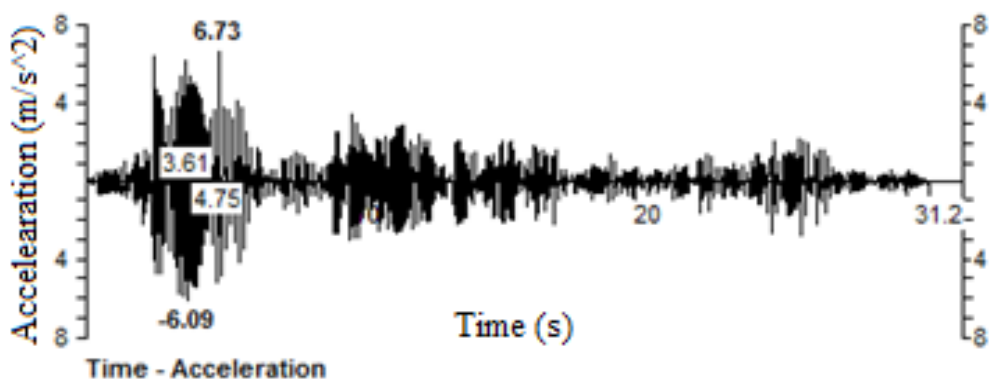

Figure 10: Time-dependent peak-to-peak acceleration along $\mathrm{x}$-direction for single story (a) unreinforced $\left(18.94 \mathrm{~m} / \mathrm{s}^{2}\right)$ and $(b)$ reinforced $\left(12.82 \mathrm{~m} / \mathrm{s}^{2}\right)$ structure

Figure 9 depicts the peak to peak lateral displacements for the time of unreinforced and reinforced single-story models along the $x$-direction. The unreinforced sample shows displacements of $8.47 \mathrm{~mm}$ at $4.88 \mathrm{~s}$ and $-9.46 \mathrm{~mm}$ at $4.97 \mathrm{~s}$ with a peak to peak displacement of $17.93 \mathrm{~mm}$ along the $\mathrm{x}$-direction. On the contrary, the reinforced sample displacements are $4.07 \mathrm{~mm}$ at $4.82 \mathrm{~s}$ and $-4.18 \mathrm{~mm}$ at $3.54 \mathrm{~s}$ with a peak to peak displacement of $8.25 \mathrm{~mm}$ along the $x$-direction. The reduction of peak to peak displacement using reinforcement is $53.98 \%$ to the $x$-direction. Figure 10 illustrates the time-dependent acceleration of the following single-story models. These accelerations are the accelerations of the identical nodes of both models. From the figures, it is clear that the reinforced one is susceptible to less acceleration compared with the unreinforced one. The unreinforced one accelerates $9.62 \mathrm{~m} / \mathrm{s} 2$ at $4.97 \mathrm{~s}$ and $9.32 \mathrm{~m} / \mathrm{s} 2$ at $4.7 \mathrm{~s}$ while the reinforced one accelerates at an acceleration of $6.73 \mathrm{~m} / \mathrm{s} 2$ at $4.75 \mathrm{~s}$ and $-6.09 \mathrm{~m} / \mathrm{s} 2$ at 3.61 s along $x$-direction. The peak of peak acceleration is reduced by $32.31 \%$ in an identical direction.

Figure 11 deliberates the time-dependent displacements of the double story mud house. Explicit differences can be observed in the graphs which denote that the use of timber splice minimizes the seismic load effect to a considerable extent. The peak to peak displacement reduces more than $70 \%$ along the $x$-direction. The timedependent accelerations of the double story mud house are shown in Figure 12. Substantial differences can be observed in the graphs which portray that the use of timber splice minimizes the seismic load effect to a considerable extent. The peak to peak acceleration is reduced by more than $20 \%$ along the $x$-direction. 
(a)

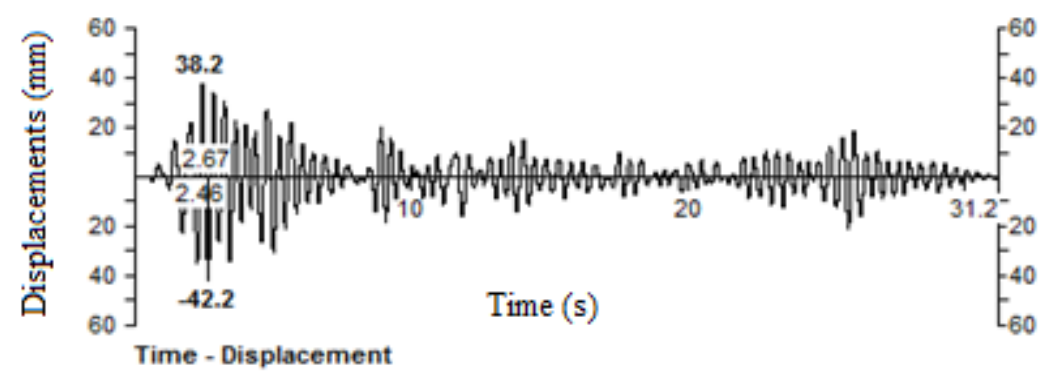

(b)

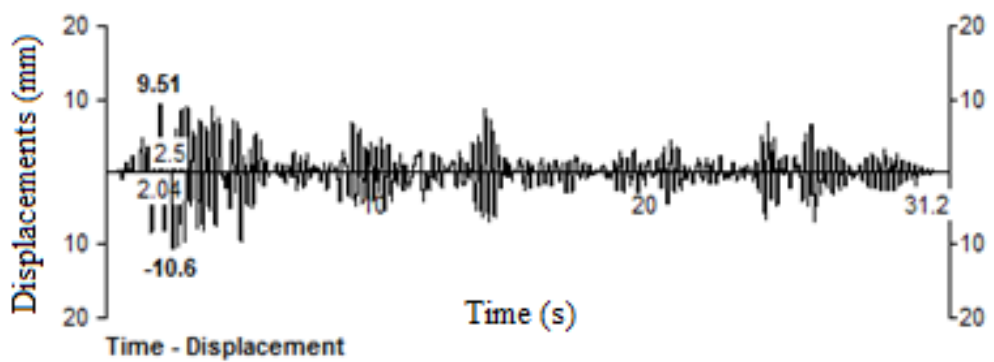

Figure 11: Time-dependent peak-to-peak displacements along $\mathrm{x}$-direction for (a) unreinforced (80.4 $\mathrm{mm})$ and (b) reinforced $(20.11 \mathrm{~mm})$ structure

(a)

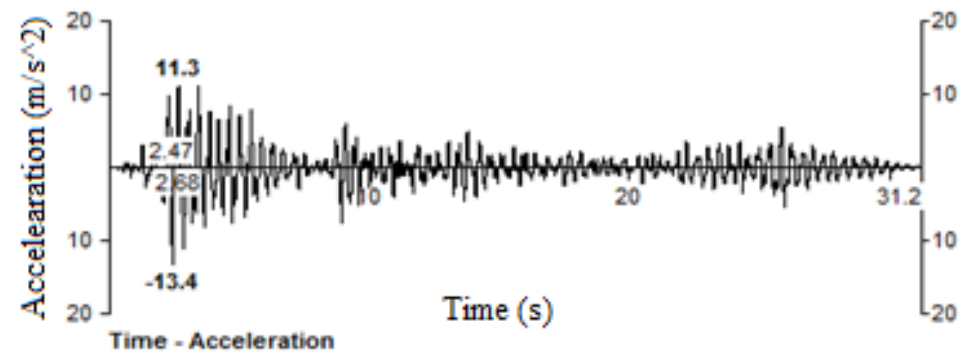

(b)

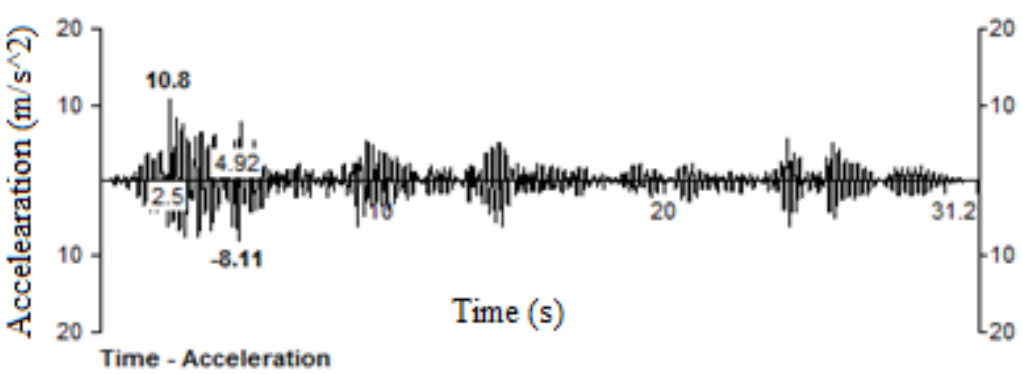

Figure 12: Time dependent peak-to-peak accelerations along $x$-direction for double story structure (a) unreinforced $\left(24.7 \mathrm{~ms}^{-2}\right)$ and (b) reinforced $\left(18.91 \mathrm{~ms}^{-2}\right)$ structure.

\section{CONCLUSIONS}

From the investigation and results obtained from numerical analysis, it is evident that using timber splices can be a good choice in mud houses. Considering the outcomes, some conclusions can be made.

1. Seismic analysis has been incorporated following three methods: equivalent static analysis, Response spectrum analysis. The results from each method have good agreements, stated through the lateral displacements. Reinforced samples are susceptible to less lateral displacements compared to the unreinforced one. It demonstrates the improvement of resistance of the structures. 
2. Free vibration analysis is incorporated and the mode shapes are obtained. It is substantial from the modal analysis that the stiffness of models is increased significantly by using timber reinforcement. The proposed timber reinforcement imparts added stiffness that improves the modal frequency. The torsion mode shifts to higher frequency which delineates the safety of reinforced models.

3. From time history analysis, the time-dependent displacement and acceleration from time history analysis also show a decent result that has good agreements with equivalent static analysis and response spectrum analysis. Peak to peak displacements and accelerations are reduced considerably.

4. Present research deals with the linear analysis of structures. Pushover analysis and non-linear time history analysis can be accomplished to apprehend the non-linear response of structures.

\section{ACKNOWLEDGEMENT}

The authors would like to thank Md. Saiful Alam Saif, Lecturer, English Language and Literature, University of Creative Technology Chittagong, for grammatical accuracy and English language standard used in this manuscript.

\section{REFERENCES}

1. Islam, M.S., and Iwashita, K. (2010). Earthquake Resistance of Adobe Reinforced by Low-Cost Traditional Materials. J. Nat. Disast. Sci., 32:1-21.

2. Meli, R., Hernandez, O., and Padilla, M. (1980). Strengthening of Adobe Houses for Seismic Actions. Proceedings of the 7th World Conference on Earthquake Engineering, Istanbul, Turkey, 465-472.

3. Ottazzi, G., Yep, J., and Blondet, M. (1988). Shaking table tests of improved adobe masonry houses. Proceedings of the 9th World Conference on Earthquake Engineering, Tokyo-Kyoto, Japan. p. 1123-1128.

4. Alam, D.M.J., Ahsan, R., Akhter, F., and Paul. A. (2014). Earthquake Resistant Non-engineered Building Construction for Rural Area in Bangladesh. http://www.iitk.ac.in/nicee/wcee/article/14_09-02-0006.PDF

5. Arya, A. (2000). Non-engineered Constructions in Developing Countries an Approach Towards Earthquake Risk Prediction. Bulletin of the New Zealand National Society for Earthquake Engineering, 33(3):187-208.

6. Uddin, N. (2008). A Study on Traditional housing Technology of Bangladesh. Indian J. Tradit. Know., 7:494500 .

7. Vargas, J., Bariola, J., and Blondet, M. (1984). Seismic strength of adobe masonry. U.S. Agency for International Development (AID) Research Project DI-84. 01.

8. Bariola, J. and Sozen, M.A. (1990). Seismic tests of adobe walls. Earthquake Spectra. 6:37-56.

9. Rahman, M., Hassan M.R., and Hossain, M.T. (2013). Seismic Performance Analysis of Mud House in the Context of Bangladesh. Int. J. Sci. Eng. Res., 4:1612-1617.

10. Illampas, R., loannou, I., \& Charmpis, D. C. (2013). Overview of the pathology, repair and strengthening of adobe structures. Int. J. Archit. Herit., 7(2): 165-188.

11. Illampas, R., Charmpis, D. C., \& loannou, I. (2014). Laboratory testing and finite element simulation of the structural response of an adobe masonry building under horizontal loading. Eng. Struct., 80: 362-376.

12. Illampas, R., loannou, I., \& Charmpis, D. C. (2017). Experimental assessment of adobe masonry assemblages under monotonic and loading-unloading compression. Mater. Struct, 50(1): 79.

13. Illampas, R., Silva, R. A., Charmpis, D. C., Lourenço, P. B., \& loannou, I. (2017). Validation of the repair effectiveness of clay-based grout injections by lateral load testing of an adobe model building. Constr. Build. Mater., 153: 174-184.

14. Illampas, R., Charmpis, D. C., \& loannou, I. (2014). Finite element simulation of the structural response of adobe masonry buildings subjected to lateral loading. Proceedings of 9th International Conference on Structural Analysis of Historical Constructions, Mexico City, Mexico, 1-12.

15. Housing and Building Research Institute. (2014). Bangladesh National Building Code.

16. Bentley Sustaining Infrastructure (2006). STAAD-pro Technical references. International Conference of Building Officials

17. 1997. Uniform Building Code.

18. Vibrationdata El Centro Earthquake Page, (1940). El centro earthquake data. http://www.vibrationdata.com/elcentro.htm 